Ethos: Jurnal Penelitian dan Pengabdian Masyarakat, Vol 8, No.2, Juni 2020: 313-318

\title{
Gender dan Mitigasi BenCana di Desa Cikole Kecamatan Lembang KABUPATEN BANDUNG BARAT
}

\section{${ }^{1}$ Ina Helena Agustina, ${ }^{2}$ Atie Rachmiatie, ${ }^{3}$ Astri Mutia Ekasari, ${ }^{4}$ Verry Damayanti, ${ }^{5}$ Riswandha Risang Aji}

\author{
1,3,4,5 Program Studi Perencanaan Wilayah dan Kota-Fakultas Teknik, Unisba, Jl Tamansari No1 \\ Bandung-40116, ${ }^{2}$ Fakultas Ilmu Komunikasi, Unisba, Jl Tamansari No1 Bandung 40116 \\ email:1'inahelena66@gmail.com, ${ }^{2}$ atierachmiatie@yahoo.com, \\ 3astrimutiaekasari@gmail.com, ${ }^{4}$ unisbavd@gmail.com, ${ }^{5}$ wrizwand@gmail.com
}

\begin{abstract}
Cikole Village, Lembang Sub-district, West Bandung District is a distaster-prone area, since it is located on Lembang fault, an active tectonic. The village has population density around 879 people/ $\mathrm{sq} . \mathrm{km}$ and the majority of them are vegetable growers, therefore most of their time is spent in agriculture land. National Disaster Management Authority (BNPB) through Government Regulation $(P P)$ number 2 year 2018 regarding Minimum service standards for disaster management requirements, issued indicators for assessing disaster resilient villages. Due to the potential of disaster, then it is necessary to describe the community's knowledge of their preparedness to become a disaster resilient village. The aim of this study is to describe the phenomenon of disaster preparedness indicators based on gender. The method used qualitative study with rationalistic approach from the grand concept of resilient village published by BNPB. Data were collected from questionnaire distribution and were analyzed with descriptive statistics. The result shows there is a different readiness between men and women in Cikole village, therefore it is necessary to establish a local community forum as a pillar of the Disaster Resilient Village.

Keywords: Cikole-Lembang, Disaster-Resillient-Village, Gender
\end{abstract}

\begin{abstract}
Abstrak. Desa Cikole Kecamatan Lembang Kabupaten Bandung Barat merupakan daerah rawan bencana,karena masuk dalam sesar lembang yang merupakan tektonik aktif.Desa dengan kepadatan penduduk 879 jiwa/km2,mayoritas penduduknya adalah petani sayur maka sebagian besar waktunya digunakan di ladang pertanian.Badan Nasional Penanggulangan Bencana (BNPB) melalui PP No 2 Tahun 2018 tentang Standar pelayanan minimal untuk kebutuhan penanggulangan bencana menerbitkan indikator penilaian desa tangguh bencana.Berdasarkan pada potensi kebencanaantersebut maka perlu mendeskripsikan pengetahuan masyarakat terhadap kesiap siagaan mereka untuk menjadi desa tangguh bencana. Tujuan penelitian ini adalah mendeskripsikan fenomena indikator kesiap siagaan bencana berdasarkan gender. Metode penelitian yang digunakan adalah menggunakan penelitian kualitatif dengan pendekatan rasionalistik dari grand concept desa tangguh bencana yang diterbitkan oleh BNPB.Pengumpulan data dilakukan dengan penyebaran kuesioner dan menganalisis dengan statistik deskriptif. Hasilnya menunjukkan adanya perbedaan kesiap siagaan antara lelaki dan perempuan di Desa Cikole, maka perlu adanya suatu forum komunitas lokal yang dibentuk untuk menjadi pilar Desa Tangguh Bencana.
\end{abstract}

Kata Kunci : Gender, Desa-Tangguh-Bencana, Cikole-Kecamatan Lembang 


\section{Pendahuluan}

Desa Cikole berada di Kecamatan Lembang Kabupaten Bandung Barat yang masuk dalam fisiografi Bandung Utara (Hindersah. H.; Agustina, I.H, I.Indratno,2017; hal 285). Desa Cikole, termasuk dalam tektonik aktif yang dipengaruhi oleh aktivitas tektonik sesar Lembang (lihat gambar1). Sesar adalah retakan atau sistem retakan sepanjang batuan yang telah mengalami pergerakan (Keller dan Pinter, dalam Meilano, I., Abidin, H.Z., Andreas, H., Gumilar, I., Sarsito, D., Hanifa, R., Rino., Harjono, H., Kato, T., Kimata, F., Fukuda,2012, Hal. 131). Penelitian paleo seismologi menunjukkan bahwa pada 500-2000 tahun yang lalu, sesar Lembang menghasilkan gempa dengan magnitudo 6.6-6.8 (Yulianto; 2011, Hal 201). Hal ini menunjukkan bahwa daerah sekitar Sesar Lembang memiliki risiko guncangan gempa yang sangat dahsyat, berakibat pada runtuhnya bangunanbangunan permanen. Desa Cikole memiliki peluang terkena guncangan gempa tersebut karena termasuk daerah teknonik aktif Sesar Lembang.

Gagasan Pembangunan SDG's menyoroti penekanan pembangunan yang bersifat kesetaraan gender. Sementara hasil penelitian Johnson, Laura B and Gary Schnakenberg (2017) menunjukkan terjadinya perbedaan dukungan di bidang pertanian terhadap petani perempuan untuk kasus di Amerika serikat. Akan tetapi patut diperhatikan untuk perempuan bahkan Flanders (2014) mengungkapkan bahwa perempuan itu memiliki peran penting sebagai keberlanjutan generasi manusia (Agustina, IH danLingga, N; 2020; p 251). Dengan demikian maka untuk Desa Cikole Kecamatan Lembang yang merupakan daerah pertanian maka gender menjadi focus karena untuk mengantisipasi

keberlanjutan pembangunan sesuai dengan SDG's (Sustainability Development Goals). Selain itu ada pertimbangan perbedaan anatomi tubuh gender yang tentunya memiliki konsekuensi dalam penanggunlangan kebencanaan di daerah rawan bencana. Tujuan penelitian mendeskripsikan kesiapsiagaan bencana berdasarkan gender.

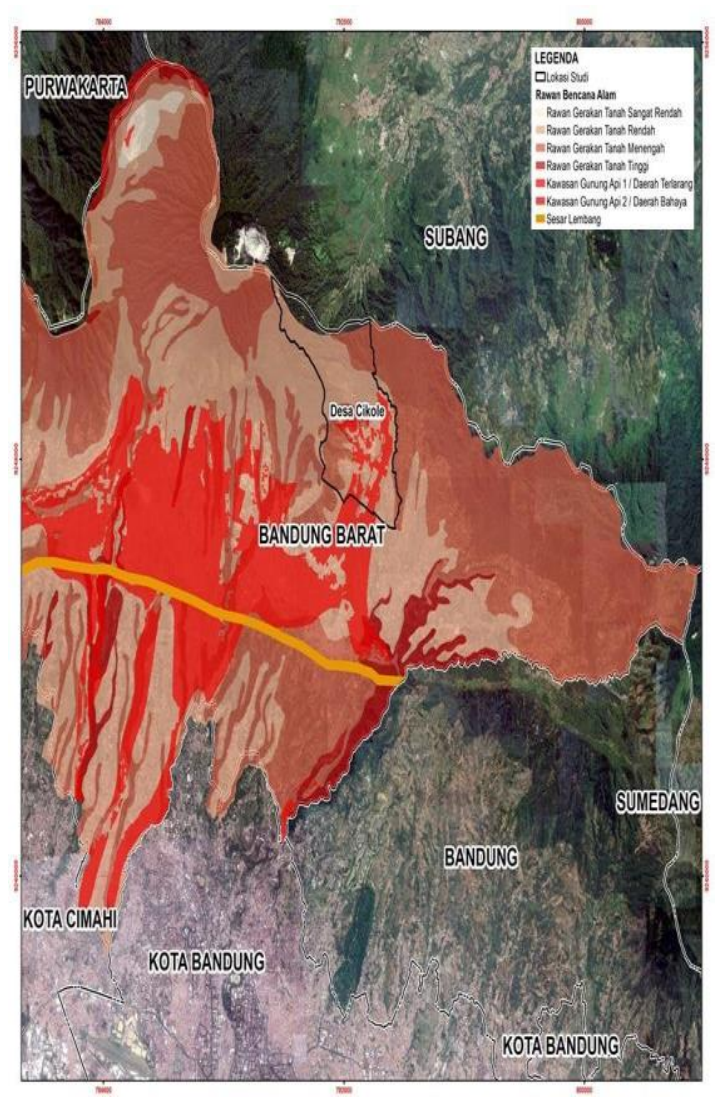

\section{Gambar 1. Posisi Desa Cikole dan Klasifikasi Rawan Bencana}

\section{Metode}

Metode penelitian menggunakan metode pendekatan rasionalistik dengan grand concept desa tangguh bencana yang ditetapkan oleh Badan Penanggulangan Bencana Nasional (BNPB). Pengumpulan data dilakukan dengan menggunakan alat kuesioner yang dibagikan kepada responden. Responden dipilih secara acak melalui 
sebaran undangan kepada ibu-ibu organisasi PKK (Pendidikan Kesejahteraan Keluarga) dan bapakbapak serta pemuda penggerak pembangunan. Dari sebaran undangan tersebut terjaring 31 responden, yang terdiri dari ibu-ibu (perempuan) sebanyak 17 orang dan bapak-bapak (laki-laki) sebanyak 14 orang. Kuesioner dibuat berdasarkan konsep kesiapsiagaan bencana. Selanjutnyanya hasil kuesioner tersebut diolah, kemudian dianalisis dengan menggunakan metode statistik deskriptif. Selanjutnya dilakukan pembahasan kualitatif dengan kajian pustaka yang menjadi landasan pemikiran studi. Lihat gambar 2 dan 3 merupakan proses survey lapangan untuk mengadakan pengisian kuesioner dan penjelasan materi kesiap siagaan bencana.

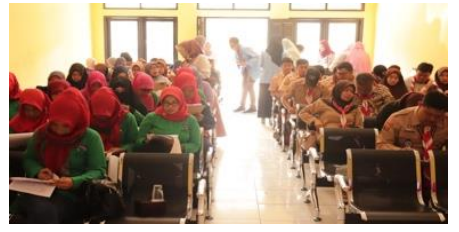

\section{Gambar 2. Suasana Pengisian} Kuesioner

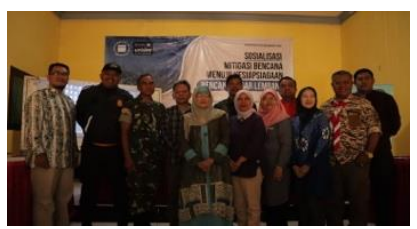

\section{Gambar 3. Pemateri Kesiap Siagaan Bencana}

\section{Hasil dan Pembahasan}

Desa Cikole Kecamatan Lembang Kabupaten Bandung Barat adalah desa pertanian hortikultura (sayuran) untuk pasokan Kota Bandung. Desa Cikole merupakan sumber pangan Kota Bandung. Kekuatan sistem pangan masyarakat terkait dengan dukungan dan pemberdayaan petani perempuan (Trauger dalam Johnson, Laura B and Gary Schnakenberg, 2017; p). Persoalan gender memiliki pengaruh terhadap produktivitas pertanian, artinya perspektif gender menjadi landasan untuk menindak lanjuti upaya pembangunan termasuk persoalan penanggulangan bencana alam.

Secara fisiografi Desa Cikole merupakan daerah pegunungan selain berpotensi sebagai kawasan pertanian, juga merupakan kawasan wisata. Potensi keruangan tersebut ditunjukkan melalui fenomena perilaku pengunjung wisata maupun investor untuk mendirikan bangunan-bangunan permanen sebagai fasilitas wisata dan memiliki pengaruh terhadap kondisi tata bangunan dan lingkungan di Desa Cikole (Hindersah, H; Ina Helena Agustina dan Imam Indratno, 2017; halaman 285). Perilaku tersebut mengakibatkan besarnya peluang terjadi kerusakan lingkungan karena daerahnya termasuk daerah rawan bencana. Pola perilaku manusia dalam sistem keruangan seperti yang terjadi di Desa Cikole tidak hanya karena factor ekonomi tetapi juga menunjukkan fenomena social (Short, dalam Agustina, I.H; Astri Mutia Ekasari, Irland Fardhani; 2018 halaman 80).

Hasil kuesioner kesiap siagaan bencana yang dirumuskan melalui 25 pernyataan, yaitu:

1. Pengetahuan tentang bencana prioritas di Jawa Barat

2. Pengetahuan rencana program manajemen risiko penanggulangan bencana

3. Pengetahuan fase rencana program

4. Pengetahuan Strategi JRCP

5. Pengetahuan tentang Reselience Citizen

6. Pengetahuan tentang Sumber Fiqih Islam tentang kebencanaan

7. Persepsi Kebencanaan sebagai azab/dosa

8. Langkah yang dilakukan ketika terjadi bencana. 
9. Pengetahuan terhadap tindakan darurat pemakaman jenazah dalam satu kafan

10. Tindakan yang dilakukan ketika bersamaan waktunya antara sholat dan bencana.

11. Pengetahuan terhadap Jenis bencana

12. Pengetahuan terhadap radio komunitas

13. Pengetahuan terhadap Peran Radio Komunitas

14. Pengetahuan alat untuk menyebarkan informasi di dalam radio komunitas

15. Pengetahuan akan tujuan pengurangan risiko bencana

16. Pengetahuan aplikasi HP/Smartphone untuk mengetahui bencana

17. Pengetahuan Aplikasi pemantauan bencana yang ditetapkan pemerintah.

18. Persepsi kegunaan aplikasi pemantauan bencana

19. Pengetahuan tentang First Aid

20. Pengetahuan konten informasi Firs Aid

21. Pengetahuan informasi inarisk

22. Pengetahuan konten informasi inarisk.

23. Pengetahuan informasi BMKG

24. Pengetahuan Potensi bencana di Desa Cikole

25. Pengetahuan Bencana di Kota Bandung.

Hasilnya pengolahan kuesioner menunjukkan bahwa $86 \%$ laki-laki dan $59 \%$ perempuan menyatakan bahwa bencana prioritas di provinsi Jawa Barat terdiri dari bencana gempa bumi, Tsunami, Gunung Merapi, Banjir ,tanah longsor dan kekeringan. Sebanyak $71 \%$ laki-laki dan $100 \%$ perempuan mengetahui program manajemen risiko penanggulangan bencana.Sebanyak 64\% laki-laki dan $76 \%$ perempuan mengetahui fase rencana program pemerintah provinsi Jabar. Sebanyak
$71 \%$ laki-laki dan $47 \%$ perempuan mengetahui strategi JRCP. Sebanyak $79 \%$ laki-laki dan $41 \%$ perempuan memiliki pengetahuan reselience citizen. Sebanyak $71 \%$ Laki-laki dan $71 \%$ perempuan mengetahui sumber fiqih Agama Islam tentang kebencanaan. Sebanyak 64\% laki-laki dan $76 \%$ perempuan menganggap kebencanaan adalah azab/dosa. Sebanyak $71 \%$ Laki-laki dan $76 \%$ perempuan mengetahui langkah yang harus dilakukan ketika terjadi bencana.Sebanyak $64 \%$ laki-laki menyatakan bahwa jenazah dapat disatukan kain kafan akan tetapi harus berdekatan, sedangkan $47 \%$ perempuan menyatakan boleh disatukan kain kafannya karena kondisi darurat. Sebanyak 57\% laki-laki dan 53\% perempuan menyatakan akan membatalkan sholat dan menyelamatkan diri manakala bencana datang pada saat sedang sholat. Sebanyak $64 \%$ laki-laki dan $76 \%$ perempuan menyatakan bencana incidental bukanlah bencana alam. Sebanyak $79 \%$ laki-laki dan $65 \%$ perempuan menyatakan bahwa radio komunitas adalah radio untuk melayani dirinya semdiri melalui radio. Sebanyak $85,7 \%$ laki-laki dan $71 \%$ perempuan menyatakan fase radio komunitas melayani pada saat fase pra bencana dan fase saat terjadi bencana. Sebanyak $71 \%$ laki-laki dan $76 \%$ perempuan menyatakan media untuk menyenarkan informasi bencana adalah social media, HP dan radio. Sebanyak 93\% laki-laki dan $41 \%$ perempuan menyatakan pengurangan risiko bencana bertujuan mengurangi kerentanan social-ekonomi terhadap bencana. Sebanyak $64 \%$ lakilaki dan $65 \%$ perempuan mengetahui aplikasi HP/smartphone untuk informasi bencana. Sebanyak 50\% laki-laki dan $59 \%$ perempuan mengetahui bahwa pemerintah sudah mengeluarkan aplikasi yang dapat dijadikan 
pemantauan bencana. Sebanyak $100 \%$ laki-laki dan $88 \%$ perempuan menyatakan aplikasi tersebut berguna. Sebanyak 43\% laki-laki menyatakan First Aid untuk bencana banjir dan 59\% perempuan menyatakan untuk bencana kekeringan. Sebanyak 86\% laki-laki dan $47 \%$ perempuan menyatakan mengetahui informasi inarisk. Sebanyak $43 \%$ laki-laki dan $65 \%$ perempuan menyatakan mengetahui konten inarisk. Sebanyak $64 \%$ laki-laki dan $47 \%$ perempuan mengetahui informasi BMKG. Sebanyak $86 \%$ laki-laki dan $71 \%$ perempuan mengetahui potensi bencana Desa Cikole yaitu gempa bumi. Sebanyak 50\% laki-laki dan 65\% perempuan mengetahui potensi bencana Kota Bandung yaitu Banjir.

Berdasarkan hasil penelitian di atas menunjukkan bahwa laki-laki dan perempuan di Desa Cikole menunjukkan kesiap siagaan yang berbeda terhadap mitigasi bencana. Laki-laki lebih memahami terhadap program pembangunan JRCP dibandingkan perempuan, maka pihak JRCP harus mampu mengkomunikasikan programnya kepada pihak perempuan. Untuk informasi dari smartphone, tampaknya perempuan lebih memiliki pengetahuan dibandingkan dengan laki-laki. Ini dapat dilihat pemahaman perempuan terhadap konten-konten First Aid, konten inarisk lebih unggul dibandingkan laki-laki. Sedangkan untuk informasi BMKG laki-laki lebih unggul dibandingkan perempuan. Tampak jika informasi cuaca (BMKG) lebih banyak diakses oleh laki-laki dibandingkan perempuan. Kemungkinan karena laki-laki lebih dominan diluar rumah sehingga membutuhkan informasi cuaca.

Hasil penelitian menunjukkan walaupun Desa Cikole merupakan desa pertanian (Data Tahun 2019 menunjukkan jumlah petani di Desa Cikole sebanyak 1739 Jiwa dari total
Jumlah penduduk 14.831 Jiwa, Sumber Penyuluh Pertanian Kecamatan Lembang) akan tetapi mereka sangat tanggap terhadap informasi. Termasuk tanggap terhadap informasi kebencanaan. Hasil kajian literatur menunjukkan bahwa lokasi kegiatan ekonomi sebagian besar bergantung pada karakteristik spasial dan karakteristik spasial termasuk atribut mikro-geografis dari lokasi tersebut (Rodrigue, Comtois, \& Slack, dalam Antipova,2015.). Rujukan tersebut menunjukkan bahwa ruang Desa Cikole sebagai ruang kegiatan pertanian merupakan ruang mikro dari kegiatan yang mendukung pertaniannya. Akan tetapi masyarakatnya ternyata mampu beradaptasi untuk informasi melalui media social. Artinya walaupun dominannya petani tetapi mereka adatif terhadap informasi terutama kebencanaan. Globalisasi membawa pengaruh positif dalam menyebarkan informasi kebencanaan, terlihat dari laki-laki maupun perempuan di desa Cikole yang mampu mengakses informasi kebencanaan melalui media social yang disediakan pemerintah.

\section{Kesimpulan dan Saran}

Hasil penelitian menunjukkan perbedaan kesiap siagaan laki-laki maupun perempuan terhadap penangulangan bencana di Desa Cikole Kecamatan Lembang Kabupaten Bandung Barat. Media social tentang informasi bencana terutama inarisk lebih banyak diketahui perempuan dibandingkan laki-laki. Sedangkan BMKG lebih banyak diketahui oleh laki-laki dibandingkan perempuan. Program JRPC lebih banyak diketahui oleh pihak laki-laki dibandingkan perempuan. Demikian pula dengan resilence nitizen, laki-laki lebih mengetahui daripada perempuan. Dapat disimpulkan adanya perbedaan pemahaman gender terhadap kesiap 
siagaan mitigasi bencana. Untuk itu maka disarankan perlu ada pembentukan forum komunitas untuk lebih menguatkan pemahaman yang sama terhadap mitigasi bencana di Desa Cikole Kecamatan Lembang Kabupaten Bandung Barat.

\section{DAFTAR PUSTAKA}

Agustina, I.H, Astri Mutia Ekasari, Irland Fardani, (2018), Sistem Ruang Keraton Kanoman dan Keraton Kacirebonan, Vol 6 No1 , Jurnal Penelitian dan Pengabdian ( Sains \&Teknologi), Halaman 68-81. Agustina, I.H dan Nadya Lingga,(2019), An analysis of the spatial phenomena of women in Cigondewah Fabric Centre, Bandung, Indonesia, IOP Conference Series; Earth and Enviromental Science, Volume 447, International conference Planning towards sustainability (ICOPS),6-7 November 2019, Surakarta, Indonesia.

Antipova, A, (2015),Black, White, male, and female concentrated employment: The effect of spatial and aspatial labor factors , Journal Cities 42 pp 160-170

H. Hindersah, I.H. Agustina, I. Indratno (2017), Pembelajaran Tata Bangunan di Desa Cikole Kecamatan Lembang Kabupaten Bandung Barat, Vol 5 No.2 (Juni, 2017) Ethos: Jurnal Penelitian dan Pengabdian (Sains \& Teknologi), Halaman 284-290.

Johnson, L. B and Gary Schnakenberg, (2017), Gedering strategies for civic agriculture: The case Blue Ridge Women in agriculture and the High Country Farm Tour, Journal of Rural Studies 55 page 181-191.

Meilano, I., Abidin, H.Z., Andreas, H., Gumilar, I., Sarsito, D., Hanifa, R., Rino., Harjono, H., Kato, T., Kimata, F., Fukuda, Y.(2012). Slip
Rate Estimation of the Lembang FaultWest Java from Geodetic Observation, Journal of Disaster Research Vol.7 No.1.

Yulianto E,(2011). Understanding the Earthquake Threat to Bandung from the Lembang fault, AustraliaIndonesia Facility for Disaster Reduction (AIFDR) Project Report, Jakarta. 